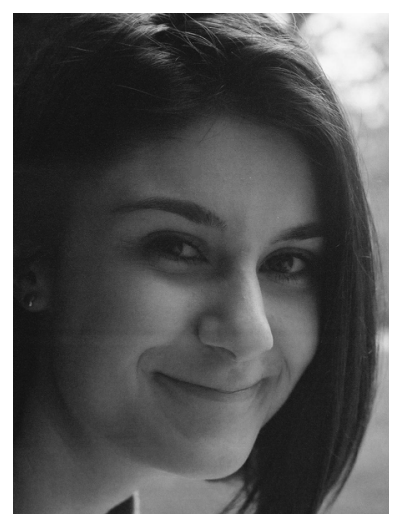

SOQUEL FILICE is a History major with a minor in Spanish and in Communication Studies. She is really interested in women's history and fashion history, which is what inspired her to write her paper about gender expression through swimsuits in the early 20th century. She enjoys knitting, reading, writing, swimming, and spending time with her friends and family. She has an insatiable desire for learning and adventure. After graduation, she is interested in pursuing a graduate degree in museum studies or learning more about women's and gender studies. She is also interested in pursuing a career in editing and writing. She is not sure yet, but she is excited to see where life takes her. 


\section{TWENTIETH CENTURY MERMAIDS: AMERICAN WOMEN ON DISPLAY}

By Soquel Filice

Before the late 1890s and into the twentieth century, men and women did not enjoy the oceans and the seashore for pure leisure. In the United States, this trend followed suit. Up until the late nineteenth century, it was not culturally acceptable for women to participate in maritime activities such as sailing, yachting, swimming, and bathing. American society considered these activities masculine until one brave Australian woman, Annette Kellerman, toured the country and claimed swimming to be "the best sport in the world for women." ${ }^{85}$ She courageously donned a "form-fitting men's style bathing suit" ${ }^{\text {" } 6}$ at beaches around the nation and encouraged American women to swim at beaches and participate in what was previously considered a man's sport. This created controversy and redefined values in American society by challenging typical roles for women based on class, race, age, and marital status. During this period, American society also objectified females and treated them as scandalous

${ }^{85}$ Annette Kellerman, How to Swim (New York: George H. Doran Company, 1918), 38.

${ }^{86}$ Syd Syramalia Lindsley, "Girl Pictures: The Politics of Sexuality and Female Display in the Twentieth-Century United States," ProQuest Dissertations and Theses, 2011, accessed May 2, 2013. 
sexual commodities in performances and advertisements. ${ }^{87}$ This paper explores the paradoxes and paradigms that defined early twentieth century American women and their pursuit of independence and leisure in the maritime sphere. By analyzing several newspapers and images from this time period, I provide insight into how changing social norms and gender roles affected American women. In the late nineteenth century and into the twentieth century, the ocean constituted not just a neutral geographic region, but also a space for constructing race, class and gender. The adoption of new women's swimsuits both allowed for the expression of female individuality and fashion, but also stereotyped American women as graceful beings with an utmost sense of poise, confidence, beauty and dignity. ${ }^{88}$

Before this time period, the average American viewed the sea as a treatment for the sick and the lame. Doctors often recommended that patients be plunged into the water until they started shivering because the cold water would toughen the patient and give life and vigor to the body. ${ }^{89}$ Physicians brought their female patients down to the beach in "bathing-machines" and dipped them into the water to protect their modesty and fragility, whereas men "remained free to pit themselves against the waves and to test their energy against that of the ocean." ${ }^{\prime \prime}$ Alain Corbin argues that therapeutic bathing transitioned into a pleasurable experience because of this gender distinction at the beach. American society thought that it was acceptable to section women off into a certain area of the water, usually closer to the shore, creating a spectacle for the men to look at. This created a need for women to find a new, modest way to dress because their bodies and clothing would be soaked by the waves. Christine Schmidt, a fashion researcher who has done extensive work on the evolution of the swimsuit, describes early women's bathing garments as

A yoked dress that was pleated, long sleeved, and belted. Drawers that extended to the ankle were attached to the dress to ensure that the body was

${ }^{87}$ Angela J. Latham, "Packaging Woman: The Concurrent Rise of Beauty Pageants, Public Bathing, and Other Performances of Female 'Nudity," Journal of Popular Culture 29, no. 3 (December 1, 1995): 156, Academic Search Elite, EBSCOhost.

${ }^{88}$ Annette Kellerman, Physical Beauty: How to Keep it (New York: George H. Doran Company, 1918), 86.

${ }^{89}$ Alain Corbin, The Lure of the Sea: The Discovery of the Seaside in the Western World 1750-1840 (Berkeley: University of California Press, 1994), 73-74.

${ }^{90}$ Ibid., 76. 
not exposed. These garments were generally made of wool or cotton and were cumbersome-restricting movement in the water... and could weigh up to thirty pounds when wet. ${ }^{91}$

These garments effectively protected women from any peeping eyes at the seashore, but limited the activities that they could enjoy. Annette Kellerman, in her book Physical Beauty: How to Keep it, says that "American women have too long been handicapped in the enjoyment of this excellent sport [swimming] by silly styles in bathing costumes that make swimming well nigh impossible." 92 Even as late as 1910, photographs show California women swimming in the San Francisco Bay fully clothed with handkerchiefs on their heads ${ }^{93}$.

Annette Kellerman was the first woman to debut her one-piece form-fitting suit in vaudeville performances, long distance swim competitions, silent films, and on beaches. Kellerman is the individual who contributed most to the evolution of the swimsuit into a unisex one piece style. ${ }^{94}$ She was born in Sydney, New South Wales Australia, in 1887. Her story is one that inspired American women because she started as a crippled little girl who was afraid of the water and bloomed into a confident, daring woman who amazed audiences not only with her "men's" swimsuit, but also with her diving and swimming feats. Even today, a children's book called Mermaid Queen, was written about "The spectacular true story of Annette Kellerman, who swam her way to fame, fortune, and swimsuit history!"95 Her significance is largely known for debuting the one-piece swimsuit, but she is also significant for the paradox that she created for twentieth century American women.

Kellerman pegged swimming as a "woman's sport" ${ }^{96}$ in her books How to Swim and Physical Beauty. She reinforced the American ideal of beauty by categorizing women as graceful, slender, poised, and confident. Kellerman encouraged the idea of swimming as an alternative to other sports and described

${ }^{91}$ Christine Schmidt, The Swimsuit: Fashion from Poolside to Catwalk (London: Berg, 2012), 7.

${ }_{92}$ Annette Kellerman, Physical Beauty, 88.

93 "Never Too Cold to Swim in the Bay," San Francisco Call 107, no. 61, January 30, 1910, California Digital Newspaper Collection, accessed May 28, 2013, http://cdnc.ucr.edu/cdnc.

${ }^{94}$ Christine Schmidt, The Swimsuit, 23.

95 Shana Corey, illustrated by Edwin Fotheringham, Mermaid Queen: The Spectacular True Story of Annette Kellerman, Who Swam Her Way to Fame, Fortune, and Swimsuit History! (New York: Scholastic Press, 2009).

${ }^{96}$ Annette Kellerman, How to Swim, 38. 
women as "a differently organised creature, and only makes herself ridiculous when she attempts to compete man-fashion in man's sports." ${ }^{\text {"97 }}$ From a twentyfirst century perspective, this quote seems very sexist. In fact both of her books that suggest that women need to be slender, beautiful, athletically fit, and not competitive with men seem sexist. However Kellerman's new bathing suits also empowered women to have their own arena to compete in and a new activity to enjoy without the restriction of "awkward, unnecessary, lumpy 'bathingsuits." "98 Annette Kellerman's life and writings suggest that bathing suits both stereotyped and gave freedom to twentieth century women. Kellerman was a controversial figure when she first set foot on American beaches because of the popularity she received and the cultural phenomenon she created. American women did not widely adopt her style of swimming suit until the 1920s, so the media used her popularity to advertise other products to women until it became culturally acceptable to wear these new swimsuits. ${ }^{99}$ Her influence spurred American women to start wearing form-fitting swimsuits, but did not necessarily provide them with more independence.

Since no other American women were wearing these types of suits at the time, some women looked to break cultural norms by wearing men's suits. A newspaper article with an unknown author in the San Francisco Call, published on July $6^{\text {th }} 1913$, exemplifies this transition between the earlier style women's suits and the more functional men's suits. The article states that on the Fourth of July, "hundreds of swimming folk" invaded Alameda Beach in California. ${ }^{100}$ The women, who arrived to the beach first, rejected their traditional bulky swimsuits and instead asked to wear the more slim-fitting men's suits. When the men arrived to the beach later in the day, there were no more men's suits, so they wore some of the women's suits into the water. The author of the article compares the sight of Alameda Beach on the fourth of July to the "Horribles," an annual parade where people dress up in grotesque costumes and walk in the streets on Independence Day ${ }^{101}$.

${ }^{97}$ Ibid.

${ }_{98}$ Ibid., 47.

${ }^{99}$ Christine Schmidt, The Swimsuit, 57.

100 "Skirtless Suits Chosen by Fair Swimmers: Male Patrons of Alameda Bathing Resort Compelled to Drape Limbs or Stay Ashore," San Francisco Call 114, no. 36, July 6, 1913, California Digital Newspaper Collection, accessed May 28, 2013, http://cdnc.ucr.edu/cdnc.

101 "Skirtless Suits Chosen by Fair Swimmers," San Francisco Call. 
Ironically, this event happened to take place on Independence Day. Although it was not published on that date, the fact that women asserted their independence by wearing non-traditional swimwear is groundbreaking. The men played along with this break in social norms and decided to jump in the water in women's suits. This event clearly broke social norms as reflected in the author's tone and declarations about this event. The San Francisco Call classifies the women who wore men's swimsuits as feminists and declares their actions to be "masculine tricks played by feminine tricksters." 102 The author also emphasizes the risqué nature of this act when he or he describes the men's suits as "the scant garment of the more undraped sex." ${ }^{103}$ These specific phrases allude to the early twentieth century social norms against cross-dressing, and more specifically showing too much skin. Additionally before the actual text of the article, a small phrase appears in parentheses that states, "Special Dispatch to the Call." 104 This text reveals that the "Alameda Independence Day Parade" was such a scandal that it had to be included in a special edition to the local newspapers.

Not only does this article reveal how women used bathing suits to express their newfound independence to break cultural norms, but it also reflects a new twentieth century ideal of fitness, feminine beauty, and bodily ideals. ${ }^{105}$ The author of the San Francisco Call article describes the women that chose to wear men's suits as "mermaids" and "sea nymphs." This article also mentions "the pretty girls in men's suits" towards the end of its text. ${ }^{106}$ Although these daring ladies surprised The San Francisco Call, their feminine qualities gave them an opportunity to be noticed for breaking social norms in these more revealing suits. With the new, more revealing style of swimsuits, American women had to be more concerned about the way that they looked because they revealed more skin than they were used to. This was a freeing experience for some, including a woman quoted in the San Francisco Call who said, "This is the first real Independence day costume I have ever worn." 107

\footnotetext{
102 Ibid.

103 Ibid.

104 Ibid.

${ }_{105}$ Christine Schmidt, The Swimsuit, 43.

106 "Skirtless Suits Chosen by Fair Swimmers," San Francisco Call.

107 Ibid.
} 
While some white women were experiencing more independence through maritime activities such as swimming, other women were not. An important lens to look through is what the author omits from this article: that maritime leisure was a new experience for some, but it excluded others. Upper-class women had time and money to experience leisure at the sea shore and wear new bathing garments such as the twentieth-century swimsuit, while African Americans and lower class women did not. African American women even had trouble trying to find a place to enjoy leisure on the beach because whites did not want to swim near them.

On June 17, 1912, Mrs. W. A. Bruce (an African American woman) fought to keep her property to provide leisure for African Americans in Redondo Beach. ${ }^{108}$ Mrs. Bruce and her friends agitated white property owners who believed swimming next to minority races not only contaminated the water, but also their social reputation. "Constables" guarded the white landowner's property, specifically a Mr. George H. Peck, and sectioned it off to be a no-trespassing zone. This zone blocked the African-American bathers from going straight out to the seashore, so much so that they had to find a different route to make it to Mrs. Bruce's property. This article alludes to the racism at the time that banned African-Americans from swimming at the "white" resorts along the coast. Mrs. Bruce even stated that if African-Americans tried to buy property to create their own resort, realtors rejected their paperwork. ${ }^{109}$ This event in Redondo Beach, California is a glimpse into early twentieth century maritime leisure. Social constructs such as race, class, and gender defined maritime leisure and made it quite a homogeneous affair.

A previous article published in the Los Angeles Times titled "They Dashed into the Sea with their Dresses On," details an event that characterizes American maritime leisure for upper-class, white members of society. On July 9, 1902, a group of "romping, rollocking, unsophisticated girls" went to the beach with the Salvation Army. ${ }^{110}$ Approximately 226 women attended this brunch by the seashore including an "Indian woman and her little babe." 111 At a first glance,

108 "Colored People's Resort Meets with Opposition," Los Angeles Times, June 27, 1912, ProQuest Historical Newspapers Los Angeles Times (1881-1989), accessed May 28, 2013.

109 "Colored People's Resort Meets with Opposition," Los Angeles Times.

110 "They Dashed into the Sea with their Dresses On," Los Angeles Times July 9, 1902, ProQuest Historical Newspapers: Los Angeles Times (1881-1989), accessed May 28, 2013.

${ }^{111}$ Ibid. 
this article displays how everyone enjoyed maritime leisure in the twentieth century. After further consideration, "They Dashed into the Sea with Their Dresses On" is an example of how the opposite is true. The author categorizes the Indian woman and her baby not as equal members of society, but as "representative" of their race. Race not only added to the segregation that happened in a maritime setting, but also further defined the controversy and paradox that American women experienced at this time.

Socioeconomic class influenced women's maritime leisure as well. Before Annette Kellerman classified swimming as a "women's sport," 112 many rich, white women enjoyed yachting and sailing. They had earlier access to the sea and participated in maritime activities before middle-class women did. ${ }^{113}$ Women who wanted to go sailing or yachting had to know how to dress and how to act while navigating a boat. American society looked at these women like novelties because they navigated boats like men, yet conducted themselves with beauty and grace. Yachting and sailing allowed these women to experience the freedom of the open sea, but men continued to stereotype them as graceful beings that still needed instruction on how to navigate the ocean. ${ }^{114}$

Fathers and husbands usually supervised and patronized a rich, white woman's access to the maritime sphere. A 1914 article from the Ogden Standard Newspaper titled "Daughters of Neptune" reveals the reluctant, paternalistic attitudes that men held about women enjoying maritime activities. Some of the women who joined yacht clubs and sailing clubs to compete with the men included Mrs. Cornelius Vanderbilt, Mrs. W. K. Vanderbilt, Mrs. Robert Goelet, and Mrs. John R. Drexel. ${ }^{115}$ These women had permission to sail around the bay

112 Annette Kellerman, How to Swim, 38.

113 For more examples of this phenomenon see "Daughters of Neptune," The Ogden Standard, August 15, 1914, accessed April 29, 2013, http://chroniclingamerica.loc.gov/lccn/ sn85058396/1914-08-15/ed-1/seq-13.pdf; "And Their Brother Sailors," San Francisco Call, August 11, 1901, accessed June 9, 2013, http://chroniclingamerica.loc.gov/lccn/sn85066387/1901-08-11/ ed-1/seq-11.pdf; Madge Moore, "The Etiquette of the Yachting Girl," San Francisco Call, September 6, 1903, accessed June 9, 2013. http://chroniclingamerica.loc.gov/lccn/sn85066387/1903-09-06/ ed-1/seq-9.pdf; Alice De Berdt, “The Social Aspect of Yachting," The Wichita Daily Eagle, October 1, 1899, accessed June 9, 2013. http://chroniclingamerica.loc.gov/lccn/sn82014635/1899-10-01/ ed-1/seq-16.pdf; "Which Outdoor Pastime is the Greatest Beauty Maker for Women?” The Sun, August 27, 1905, accessed June 9, 2013, http://chroniclingamerica.loc.gov/lccn/sn83030272/190508-27/ed-1/seq-26.pdf.

${ }_{114}$ Ibid.

115 "Daughters of Neptune," The Ogden Standard. 
because of their strong familial lineage and upper-class privilege. The pictures of these women clearly show their inherent wealth because of the excessive jewelry, purses, and crowns that they wore. ${ }^{116}$ "Daughters of Neptune" reflects the worries that men had about changing gender roles when it states, "man will have to surrender another one of his activities... Woman is going to run the yachts in a few years and send mere man back to the business office to make more money." 117 The author is upset by the fact that woman is yachting and that man is going to be sent back to work. Throughout the article, the author grows more accustomed to these brave yachtswomen and says, "It is nothing unusual for a skipper to meet women of the sea far out of sight of land, fearing nothing." 118

American society reacted similarly when women started wearing bathing suits and swimming more regularly. When some California women swam in the San Francisco Bay during winter and a group of New Yorkers passed by, they were very surprised to see so many women in the water. The San Francisco Call chronicled their reaction when these bystanders stated, "Are they mermaids or human beings, or is it an optical delusion or a mirage?" 119 Americans were not really sure what to do when women started to wear what most people considered "men's suits." American women who participated in water sports were seen as anomalies, just like Annette Kellerman, who inspired them to wear form-fitting suits that they could move in.

Although the early twentieth century is seen as a period where American women started to express their independence through politics, fashion, and sports, I would call this periodization into question because of a lack of individual expression and equality to men. Paternalistic attitudes and reluctance to accept women into the maritime sphere restricted some women from enjoying yachting and sailing, while giving freedom to others. Race and socioeconomic class further defined the exclusivity of the maritime because minority and poor women had limited access to the beach. Swimming and other maritime leisure activities created an arena where women were put on display and seen

\footnotetext{
116 Ibid.

117 Ibid.

${ }^{118}$ Ibid.

119 "Never Too Cold to Swim in the Bay." San Francisco Call.
} 
as anomalies like the vaudeville performances of Annette Kellerman. ${ }^{120}$ Early twentieth century American women started to wear more revealing swimwear that allowed them to move freely in the water, but these changes did not completely eradicate earlier stereotypes given to women. Kellerman opened up the conversation to change this stereotype, but it would take decades for these same women to be considered equal members of American society.

${ }^{120}$ Katherine H. Adams, Michael L. Keene, and Jennifer C. Koella. Seeing the American Woman, 1880-1920: The Social Impact of the Visual Media Explosion (Jefferson, North Carolina: McFarland \& Company, Inc., Publishers, 2012). 

Adams, Katherine H., Michael L. Keene, and Jennifer C. Koella. Seeing the American Woman, 1880-1920: The Social Impact of the Visual Media Explosion. Jefferson, North Carolina: McFarland \& Company, Inc., Publishers, 2012.

"And Their Brother Sailors." San Francisco Call, August 11, 1901. Accessed June 9, 2013. http://chroniclingamerica.loc.gov/lccn/sn85066387/1901-08-11/ed-1/seq-11.pdf.

“Colored People’s Resort Meets With Opposition.” Los Angeles Times, June 27, 1912. ProQuest Historical Newspapers: Los Angeles Times (1881-1989). Accessed May 28, 2013.

Corbin, Alain. The Lure of the Sea: The Discovery of the Seaside in the Western World 1750-1840. Berkeley: University of California Press, 1994.

Corey, Shana. Mermaid Queen: The Spectacular True Story of Annette Kellerman, Who Swam Her Way to Fame, Fortune, and Swimsuit History! New York: Scholastic Press, 2009.

"Daughters of Neptune." The Ogden Standard, August 15, 1914. Accessed April 29, 2013. http://chroniclingamerica.loc.gov/lccn/sn85058396/1914-08-15/ed-1/seq-13.pdf.

De Burdt, Alice. "The Social Aspect of Yachting." The Wichita Daily Eagle, October 1, 1899. Accessed June 9, 2013. http://chroniclingamerica.loc.gov/lccn/ sn82014635/1899-10-01/ed-1/seq-16.pdf.

Kellerman, Annette. How to Swim. New York: George H. Doran Company, 1918. Physical Beauty: How to Keep it. New York: George H. Doran Company, 1918.

Latham, Angela J. "Packaging Woman: The Concurrent Rise of Beauty Pageants, Public Bathing, and Other Performances of Female 'Nudity." Journal of Popular Culture 29 no. 3, (December 1, 1995): 149-167. Accessed May 3, 2013. Academic Search Elite. EBSCOhost.

Lindsley, Syd Saramalia. "Girl Pictures: The Politics of Sexuality and Female Display in the Twentieth-Century United States." ProQuest Dissertations and Theses (2011). 
Moore, Madge. "The Etiquette of the Yachting Girl." San Francisco Call, September 6, 1903. Accessed June 9, 2013. http://chroniclingamerica.loc.gov/lccn/ sn85066387/1903-09-06/ed-1/seq-9.pdf.

"Never Too Cold to Swim in the Bay." San Francisco Call 107, no. 61, January 30, 1910. Accessed May 28, 2013. California Digital Newspaper Collection.

"Skirtless Suits Chosen by Fair Swimmers: Male Patrons of Alameda Bathing Resort Compelled to Drape Limbs or Stay Ashore," San Francisco Call 114, no. 36, July 6, 1913.

“They Dashed to the Sea With Their Dresses On." Los Angeles Times July 9, 1902. ProQuest Historical Newspapers: Los Angeles Times (1881-1989). Accessed May 28, 2013.

"Which Outdoor Pastime is the Greatest Beauty Maker for Women?" The Sun, August 27, 1905. Accessed June 9, 2013. http://chroniclingamerica.loc.gov/lccn/ sn83030272/1905-08-27/ed-1/seq-26.pdf. 